\title{
Molecular etiopathology of naturally occurring reproductive diseases in female goats
}

\author{
V. Beena ${ }^{1}$, R. V. S. Pawaiya ${ }^{1}$, K. Gururaj ${ }^{1}$, D. D. Singh ${ }^{1}$, A. K. Mishra ${ }^{1}$, N. K. Gangwar ${ }^{1}$, V. K. Gupta ${ }^{2}$, R. Singh ${ }^{3}$,
}

A. K. Sharma ${ }^{3}$, M. Karikalan ${ }^{3}$ and Ashok Kumar ${ }^{1}$

1. Division of Animal Health, ICAR-Central Institute for Research on Goats, Makhdoom, Farah, Mathura - 281122 , Uttar Pradesh, India; 2. Centre for Animal Disease Research and Diagnosis (CADRAD), ICAR-Indian Veterinary Research Institute, Izatnagar - 243 122, Uttar Pradesh, India; 3. Division of Pathology, ICAR-Indian Veterinary Research Institute, Izatnagar - 243 122, Uttar Pradesh, India.

Corresponding author: R. V. S. Pawaiya, e-mail: rvspawaiya@gmail.com

Co-authors: VB: drbeenadevs@gmail.com, KG: guruvet@gmail.com, DDS: drdd2005@gmail.com, AKM: anilmishradr@gmail.com, NKG: neerajvet15@rediffmail.com, VKG: gupta.drvivek@gmail.com, RS: rajendra_singh5747@rediffmail.com, AKS: aksharmaivri@rediffmail.com, MK: karyvet11@gmail.com, AK: akumar63@gmail.com

Received: 10-03-2017, Accepted: 26-07-2017, Published online: 22-08-2017

doi: 10.14202/vetworld.2017.964-972 How to cite this article: Beena V, Pawaiya RVS, Gururaj K, Singh DD, Mishra AK, Gangwar NK, Gupta VK, Singh R, Sharma AK, Karikalan M, Kumar A (2017) Molecular etiopathology of naturally occurring reproductive diseases in female goats, Veterinary World, 10(8): 964-972.

\begin{abstract}
Aim: The aim of the present study was to investigate the molecular etiopathology of occurrence of reproductive diseases in female goats. Reproductive diseases in goats account for major economic losses to goat farmers in terms of valuable loss of offspring and animal productivity.

Materials and Methods: A total of 660 female genitalia were examined for pathological conditions (macroscopic and microscopic lesions). The etiopathological study was carried out for the presence of pathogenic organisms such as Brucella, Chlamydia, and Campylobacter in the uterus and ovary. Based on the microscopic lesions, suspected samples were subjected to diagnostic polymerase chain reaction (PCR) for various etiological agents employing 16srRNA genus specific primers for Campylobacter and Chlamydophila and OMP31 gene-based PCR for Brucella melitensis and nested PCR using ITS-1 gene primers for Toxoplasma gondii. For Brucella suspected samples, immunohistochemistry (IHC) was also performed.

Results: In studied female genitalia, 108 (16.30\%) showed gross abnormalities with overall 23.32\% occurrence of pathological conditions (macroscopic and microscopic lesions). Pathological involvement of the uterus was the highest $68(62.96 \%)$, followed by the ovaries $27(25 \%)$ and other organs. Major uterine condition observed was endometritis (5.60\%). In uterine infections, 35 (5.30\%) samples were found positive for Campylobacter spp., 12 (1.81\%) samples for B. melitensis, and $3(0.45 \%)$ samples were positive for Chlamydophila spp. Among the samples positive for B. melitensis by PCR, 3 were found positive by IHC also. Corynebacterium ovis was detected by PCR using specific primers in a case of hydrosalpinx. It was concluded that many pathological lesions in female genitalia of functional significance play a major role in infertility in goats.
\end{abstract}

Conclusion: The present study concluded that many pathological lesions in female genitalia of functional significance play a major role in infertility in goats.

Keywords: Brucella melitensis, Campylobacter spp., Chlamydophila spp., Corynebacterium ovis, etiopathology, female genitalia, goat, ovary, reproductive diseases, uterus.

\section{Introduction}

Goats are multipurpose animals, producing meat, milk, skin, and hair and contribute greatly to food, rural employment, and gross domestic product. Genital abnormalities play an important role in animal breeding either by causing infertility or sterility and thus inflict heavy economic losses [1]. Lesions affecting the uterus and ovary greatly contribute to infertility or sterility in goats and hence compromise enterprise profitability. Susceptibility

Copyright: Beena, et al. Open Access. This article is distributed under the terms of the Creative Commons Attribution 4.0 International License (http://creativecommons.org/licenses/by/4.0/), which permits unrestricted use, distribution, and reproduction in any medium, provided you give appropriate credit to the original author(s) and the source, provide a link to the Creative Commons license, and indicate if changes were made. The Creative Commons Public Domain Dedication waiver (http://creativecommons.org/ publicdomain/zero/1.0/) applies to the data made available in this article, unless otherwise stated. for reproductive abnormalities increases with age of the animal [2].

The major reproductive disorders in goats are abortion, retention of placenta, and stillbirth [3]. Dunn [4] analyzed the diseases of the periparturient goat mainly as dystocia and metritis. Reproductive tract lesions reduce the feed conversion efficacy and thereby reduce milk production and pregnancy rate and forcing the owners to cull the animal $[5,6]$. According to a study in goats, the uterus exhibited the highest (14.6\%) prevalence of genital lesions [7], whereas endometritis and ovarian cysts were the most common abnormalities in the slaughtered ewes [8]. The most common infections to cause abortion and infertility in ewes are chlamydia and toxoplasmosis [9].

There is scanty published information regarding etiopathology and prevalence of various abnormalities in Indian goats [10,11]. The pathological 
investigation of abattoir specimens provides a great deal of information on the types and prevalence of genital tract lesions and abnormalities due to infections. Information on occurrence of major infectious causes of diseases of female reproductive system of goats could help in proper diagnosis and suitable preventive and control measures. Moreover, slaughter of infected animals is of great public health concern. Therefore, the prevalence and the pathological lesions produced specifically by organisms of public health importance (Brucella, Chlamydia, Campylobacter, and Toxoplasma) were investigated in this study.

\section{Materials and Methods}

\section{Ethical approval}

The study was conducted after due approval from IAEC and CPCSEA.

\section{Collection of reproductive organs}

Female reproductive organs were collected from 660 goats from different locations in the Uttar Pradesh, Haryana, and Delhi states. The organs were collected immediately after slaughter of goats and transported to the pathology laboratory of the institute for further studies. In the laboratory, detailed examination of reproductive organs was carried out, and gross pathological changes were recorded. The representative tissue samples were preserved in $10 \%$ neutral buffered formalin for histopathological and immunohistochemical studies and refrigerated for molecular and isolation studies.

\section{Histopathology}

Formalin-fixed tissues were processed routinely and paraffin-embedded tissue sections of 4-5 $\mu \mathrm{m}$ thickness were obtained with the help of semiautomatic rotary microtome (Leica RM 2145, Germany). The sections were stained with hematoxylin and eosin following earlier described procedures [12], and the slides were examined under light microscope for histopathological changes.

\section{Immunohistochemistry (IHC)}

IHC technique was employed on formalin-fixed paraffin-embedded tissue sections for the detection of Brucella Melitensis specific antigen in the suspected cases which were positive by polymerase chain reaction (PCR) technique [13]. About $5 \mu \mathrm{m}$ thick sections were taken on 3-aminopropyl-triethoxysilane (SigmaAldrich, USA) adhesive coated slides. Antigen retrieval for OMP31 (outer membrane protein) was done by microwave irradiation of tissue sections in $10 \mathrm{mM}$ sodium citrate buffer ( $\mathrm{pH}$ 6) for $5 \mathrm{~min}$. Thereafter, the slides were incubated in $3 \% \mathrm{H}_{2} \mathrm{O}_{2}$ in absolute methanol to quench the endogenous peroxidase, and blocking was done by $5 \%$ bovine serum albumin to decrease background staining. Immunostaining for OMP31 was performed by standard avidin-biotin complex (ABC) method, following the manufacturer's instruction provided along with the product. Rabbit polyclonal antibody pSer167 (Sigma-Aldrich, USA; Product No.
E7905) was used as a specific primary antibody (1:200 dilution) against OMP31 B. melitensis antigen. The diluent (1\% phosphate buffered saline) alone was used as a negative control. A positive control slide of tissue known to contain the Brucella antigen was also used. Biotinylated goat anti-rabbit immunoglobulin $G$ was used as secondary antibody followed by incubation with extra-avidin peroxidase (Sigma-Aldrich, USA; Product No. E8386). Chromogen 3-amino-9-ethylcarbazole was used as substrate for which produced brick red positive color reaction. The sections were counterstained with Mayer's hematoxylin, mounted with glycerol gelatin, and observed under light microscope.

\section{PCR}

Tissue samples stored in deep freeze $\left(-20^{\circ} \mathrm{C}\right)$ were used for DNA extraction using commercially available QIAamp DNA Mini Kit (Qiagen, USA; Cat No./ID 51304). Around $100 \mu \mathrm{l}$ of DNA was extracted from each tissue sample (mainly uterus) and performed PCR for B. melitensis [14], Toxoplasma gondii [15], Campylobacter spp., and Chlamydophila spp. [16], using a pair of species-specific primers for B. melitensis, $T$. gondii, and genus-specific primers for Chlamydia spp. and Campylobacter spp. as well as Corynebacterium spp. from published primers [17]. For Campylobacter spp., primers were designed from the conservative 16srRNA sequence using BioEdit [18]. The amplified products were subjected to gel electrophoresis in $1.5 \%$ safe view gel stained Tris-acetate-ethylenediaminetetraacetic acid agarose and visualized under ultraviolet trans-illuminator. The primers used in the current study are given in Table-1.

\section{Isolation and identification of Brucella}

Tissue samples preserved at $4^{\circ} \mathrm{C}$ were used for isolation studies. For isolation of Brucella, a loopful of tissue scrapings were inoculated by spreading on plates of sterile Brucella agar with Hemin and Vitamin $\mathrm{K} 1$ (HiMedia, Mumbai) and incubated at $37^{\circ} \mathrm{C}$ for $48 \mathrm{~h}$. Confirmation of the pure culture was done using biochemical tests (result not shown) and staining.

\section{Results}

Intact female reproductive tracts were collected from 660 goats slaughtered in abattoirs at different locations in the Uttar Pradesh, Haryana, and Delhi states as well as from postmortem house of the institute. Of 660 female genitalia examined, 108 (16.30\%) showed gross abnormalities, with overall $23.32 \%$ $(154 / 660)$ occurrence of pathological conditions (macroscopic and microscopic lesions). Among 108 grossly abnormal genitalia, pathological involvement of the uterus was the highest $68(62.96 \%)$ followed by ovaries $(27 ; 25 \%)$, with the overall occurrence of $12.42 \%$ and $6.06 \%$, respectively. Of uterine pathologies, endometritis $(37 / 660 ; 5.60 \%)$ was the major condition observed.

During the study, DNA was extracted from 76 samples suspected for infections. Out of 76 samples 
selected, $35(5.30 \%)$ samples were found to be positive for Campylobacter spp., 12 (1.81\%) for B. melitensis, and $3(0.45 \%)$ for Chlamydia. However, T. gondii infection could not be detected in any of the cases using single tube nested PCR. In one hydrosalpinx case, Corynebacterium ovis (or C. pseudotuberculosis) was detected by PCR using specific primers. The results for PCR tests are shown in Table-2.

Consequent on PCR amplification and agarose gel electrophoresis of the DNA extracted from tissue samples, a $277 \mathrm{bp}$ amplicon was observed in Chlamydia-positive samples (Figure-1), in B. melitensis-positive samples, $1.1 \mathrm{~kb}$ size amplicon (Figure-2), in Campylobacter-positive samples, 276 bp amplicon (Figure-3), and in C. ovis-positive samples, $815 \mathrm{bp}$ amplicon (Figure-4) was observed.

In the present investigation, $B$. melitensis infection was detected in $12(1.81 \%)$ cases, which was confirmed by species-specific (OMP-31) PCR as well as by bacterial isolation in Brucella agar media containing 5\% defibrinated sheep blood. After 4-day incubation, Brucella growth colonies characterized by round, $1-2 \mathrm{~mm}$ in diameter, convex and pearly white, with smooth margins, translucent, and pale honey-colored colonies were observed (Figure-5). Later, the colonies became larger and slightly darker. On microscopic examination of stained slides of colonies in oil immersion $(100 \times)$, the organisms were seen as Gram-negative coccobacilli or pleomorphic short rods, arranged singly or in pairs or in small groups (Figure-6).
Of $2(1.29 \%)$ cases of hydrosalpinx, one showed the presence of C. ovis, and it was isolated in 5\% sheep blood agar, and stained bacterial growth colonies showed the presence of Gram-positive bacilli arranged as Chinese letters or in "palisade" arrangement (Figures-7 and 8).

Grossly, the major pathological lesions noticed in the uterus were petechial hemorrhages over caruncular tips with small, raised, whitish foci scattered in the area (Figure-9). Microscopically, tissue sections showed the presence of hemosiderin deposition with mild-to-severe cellular reactions, comprising predominantly lymphocytes and macrophages (Figure-10). Majority of such of lesions were seen in association with Campylobacter infection confirmed by 16srRNA

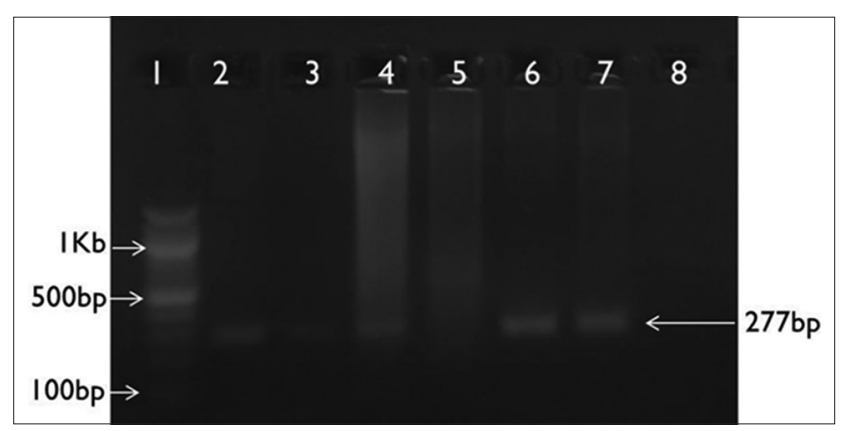

Figure-1: Chlamydophila spp. 16srRNA gene-based polymerase chain reaction. Lane 1: 100 bp ladder; Lane 2: Positive control; Lane 3-7: Unknown samples; Lane 8: No template control.

Table-1: List of primers used for PCR amplification for various organisms.

\begin{tabular}{|c|c|c|c|}
\hline Organisms & Name of primer & Primer sequence & Size of PCR products \\
\hline B. melitensis & OMP-31 & $\begin{array}{l}\text { F: 5'-TGACAGACTTITCGCCGAA-3' } \\
\text { R: 5'-TATGGATTGCAGCACCGC-3R: }\end{array}$ & $1.1 \mathrm{~kb}$ \\
\hline Chlamydophila spp. & 16SrRNA & $\begin{array}{l}\text { F: 5'-TGTCGTCAGCTCGTGTCGTG-3' } \\
\text { R: 5'-TCTACGATTACTAGCGATTCCG-3' }\end{array}$ & 277 bp \\
\hline Campylobacter spp. & 16SrRNA & $\begin{array}{l}\text { F: 5'-TGTCGTCAGCTCGTGTCGTG-3' } \\
\text { R:5'-TCTACGATTACTAGCGATTCCG-3' }\end{array}$ & 276 bp \\
\hline $\begin{array}{l}\text { T. gondii (nested } \\
\text { PCR) }\end{array}$ & $\begin{array}{l}\text { Ex:NN1 } \\
\text { NN2 } \\
\text { In:TgNP1 } \\
\text { TgNP2 }\end{array}$ & $\begin{array}{l}\text { F: 5'-CCTTTGAATCCCAAGCAAAACATGAG-3' } \\
\text { R: 5'-GCGAGCCAAGACATCCATTGCTGA-3' } \\
\text { F: 5'-GTGATAGTATCGAAAGGTAT-3' } \\
\text { R: 5'-ACTCTCTCTCAAATGTTCCT-3' }\end{array}$ & 227 bp \\
\hline C. ovis & 16SrRNA & $\begin{array}{l}\text { F: 5'-ACCGCACTITAGTGTGTGTG-3' } \\
\text { R: 5'-TCTCTACGCCGATCTTGTAT-3' }\end{array}$ & $815 b p$ \\
\hline
\end{tabular}

$\mathrm{F}=$ Forward primer, $\mathrm{R}=$ Reverse primer, $\mathrm{Ex}=$ External primer, In=Internal primers, $B$. melitensis=Brucella melitensis,

T. gondii=Toxoplasma gondii, C. ovis=Corynebacterium ovis, $\mathrm{PCR}=$ Polymerase chain reaction

Table-2: Results of PCR tests employed on tissue specimens of reproductive organs of female goats.

\begin{tabular}{lccccc}
\hline Pathogenic organisms & $\begin{array}{c}\text { Total number of } \\
\text { cases selected } \\
\text { for PCR }\end{array}$ & $\begin{array}{c}\text { Number } \\
\text { of positive } \\
\text { cases by PCR }\end{array}$ & $\begin{array}{c}\text { Incidence out } \\
\text { of total PCR } \\
\mathbf{n = 7 6}(\mathbf{\%})\end{array}$ & $\begin{array}{c}\text { Incidence out } \\
\text { of total samples } \\
\text { collected } \\
\mathbf{n = 6 6 0}(\mathbf{\%})\end{array}$ & $\begin{array}{c}\text { Incidence out of } \\
\text { total pathological } \\
\text { lesions n=154 (\%) }\end{array}$ \\
\hline $\begin{array}{l}\text { B. melitensis } \\
\text { Chlamydia spp. }\end{array}$ & $\mathrm{N}=76$ & 12 & 15.78 & 1.81 & 7.79 \\
Campylobacter spp. & & 3 & 3.94 & 0.45 & 1.94 \\
T. gondii & & 35 & 46.05 & 5.30 & 22.72 \\
C. ovis (pseudotuberculosis) & & 0 & 0 & 0 & 0 \\
Total & 76 & 1 & 1.31 & 0.15 & 0.64 \\
\hline
\end{tabular}

B. melitensis=Brucella melitensis, T. gondii=Toxoplasma gondii, C. ovis=Corynebacterium ovis, PCR=Polymerase chain reaction 


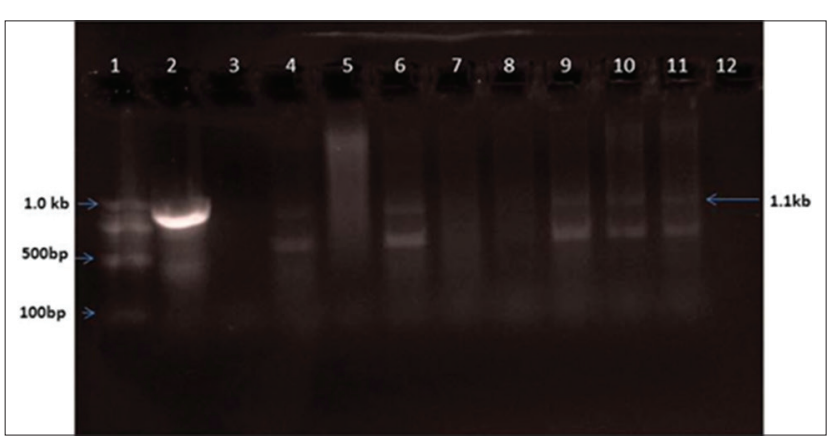

Figure-2: Brucella melitensis OMP31 gene-based polymerase chain reaction. Lane 1: 100 bp ladder; Lane 2: Positive control; Lane 3-11: Unknown samples; Lane 12: No template control.

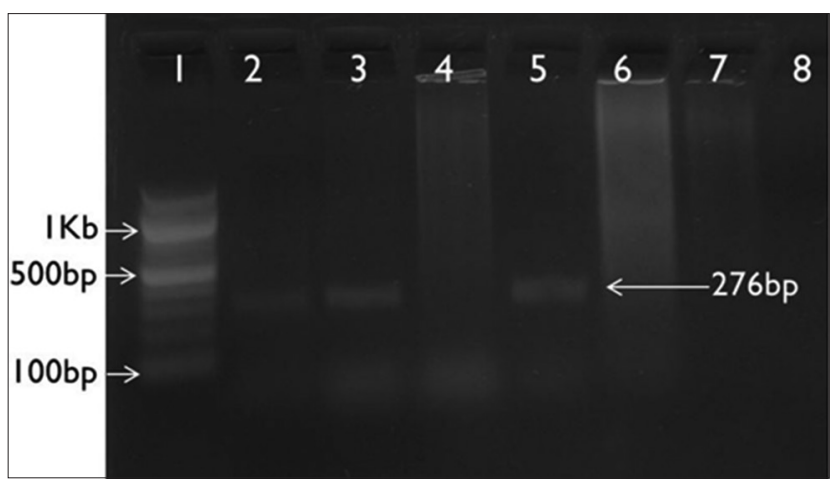

Figure-3: Campylobacter spp. 16srRNA gene-based polymerase chain reaction. Lane 1: 100 bp ladder; Lane 2: Positive control; Lane 3-7: Unknown samples; Lane 8: No template control.

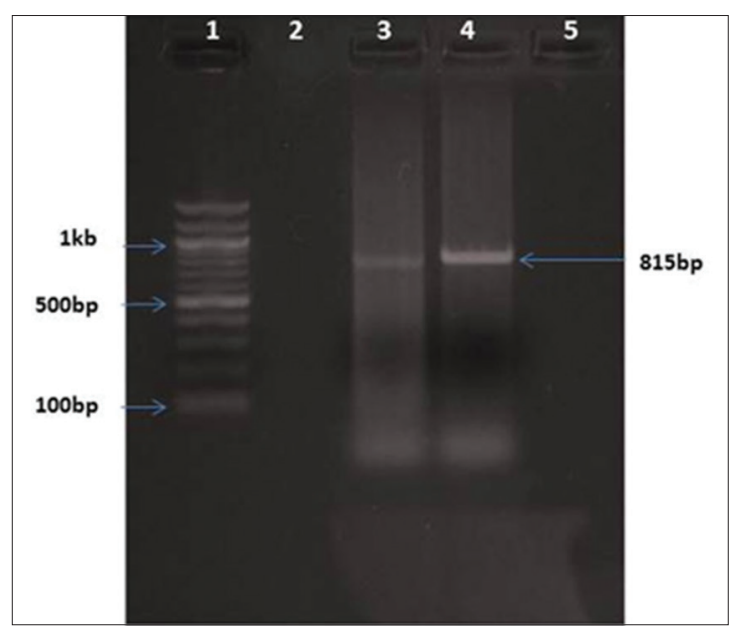

Figure-4: Corynebacterium ovis 16srRNA gene-based polymerase chain reaction. Lane 1: 100 bp ladder; Lane 2: Positive control; Lane 3: Unknown samples; Lane 4: No template control.

PCR. Acute endometritis lesions were microscopically characterized by mucosal and submucosal infiltration of neutrophils in wide areas admixed with lymphocytes and plasma cells and cellular debris associated with multifocal erosions of the superficial epithelium (Figure-11). Chronic purulent endometritis was histologically characterized by the presence of large central core area of organized pus with abundant neutrophils, irregular calcification areas surrounded by neutrophils

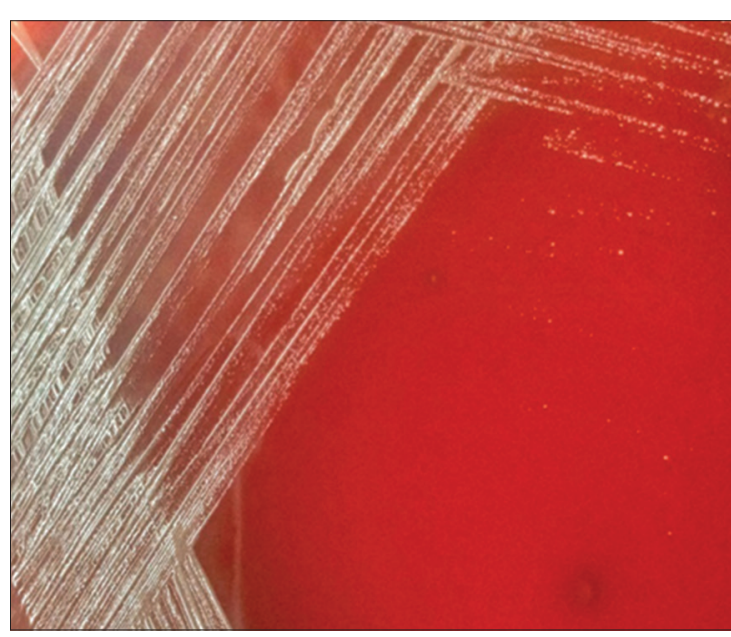

Figure-5: Brucella colonies were pearly white, with smooth margins, translucent in brucella blood agar.

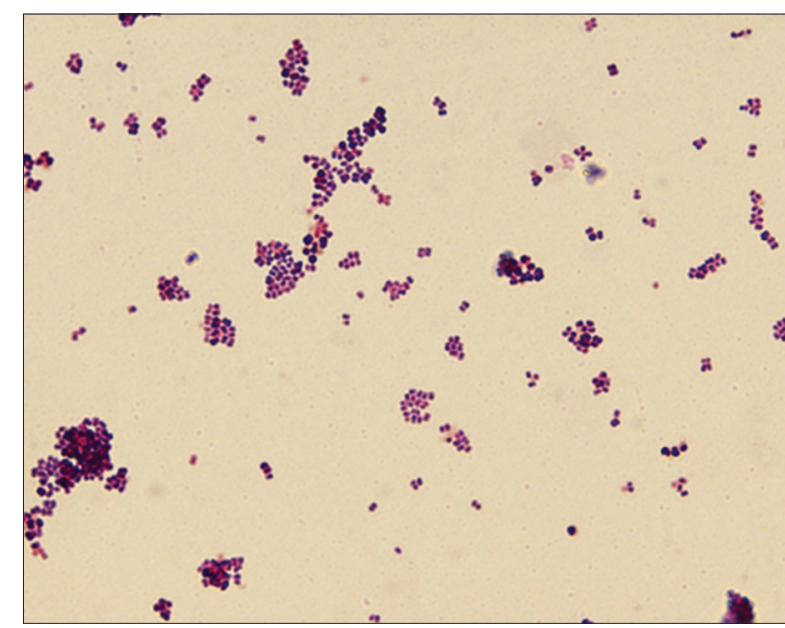

Figure-6: Brucella organisms were seen as coccobacilli/ pleomorphic short rods, arranged singly or in pairs or in small groups (Gram's stain, 1000x).

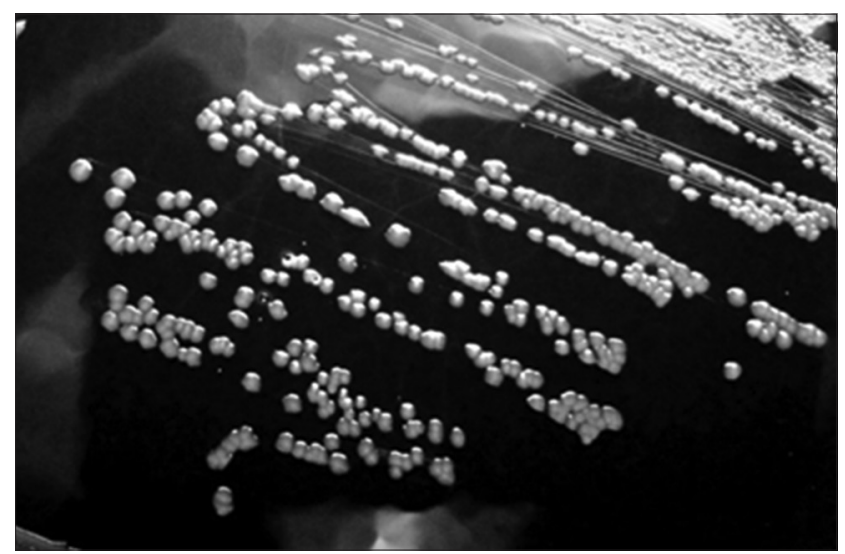

Figure-7: Corynebacterium ovis: Circular, convex, and grayish colonies on blood agar.

predominantly admixed with macrophages and lymphocytes and occasionally foreign-body type giant cells and fibrous encapsulation (Figure-12). The mucosal and submucosal area got infiltrated with lymphocytes; chronic endometritis with fibroplasia and atrophy of glands were noticed. In this sample, Campylobacter infection was confirmed by PCR. 


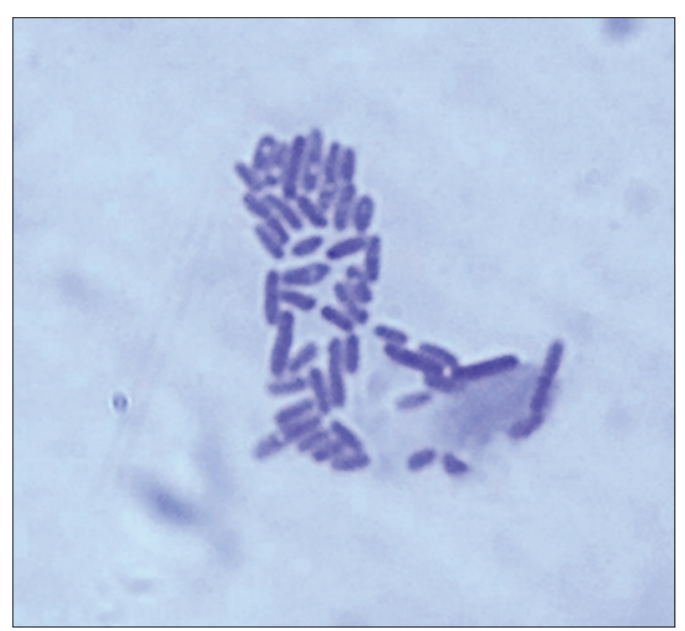

Figure-8: Corynebacterium ovis: Gram-positive pleomorphic rods arranged like "Chinese letters" (Gram's stain, 1000x).

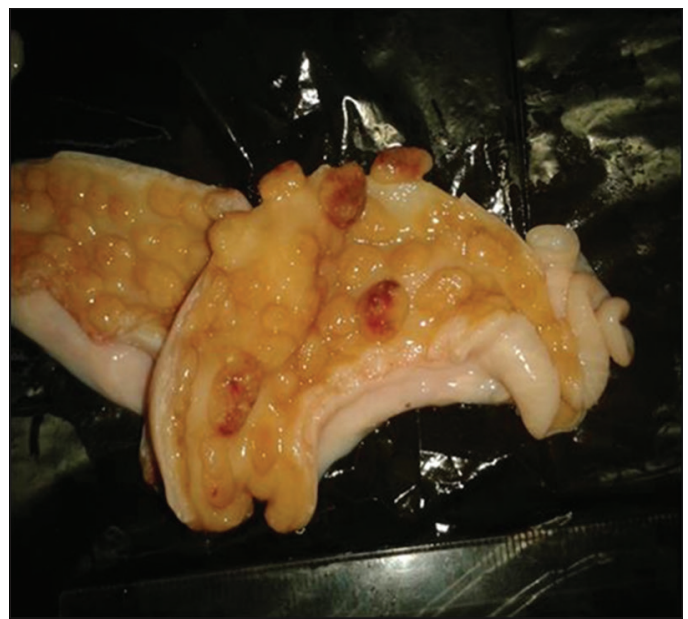

Figure-9: Uterus: Caruncular tips showing necrotic foci and petechial hemorrhages.

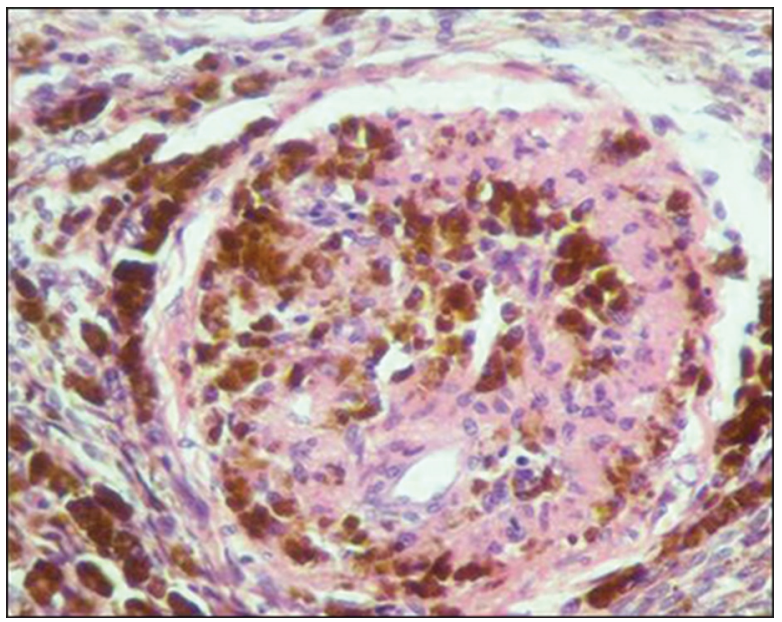

Figure-10: Uterus: Hemosiderin deposition in the caruncular area (hematoxylin and eosin, 400x).

Chronic nonpurulent endometritis was histopathologically characterized by the presence of diffuse or focal lymphocytic infiltration, macrophages, plasma cells and fibroblast in the lamina propria, and multifocal desquamation of surface epithelium leaving behind

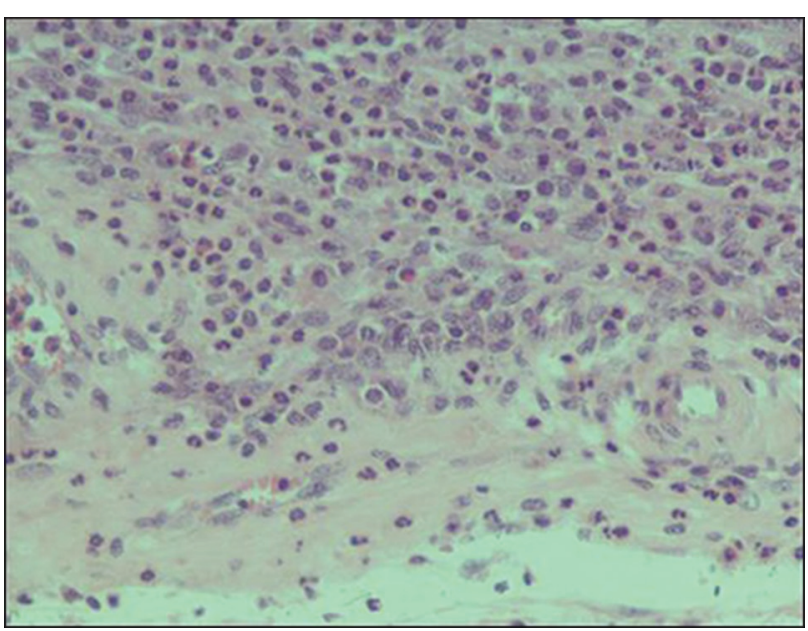

Figure-11: Acute endometritis: Infiltration of neutrophils, lymphocytes, and plasma cells (hematoxylin and eosin, $400 \times)$.

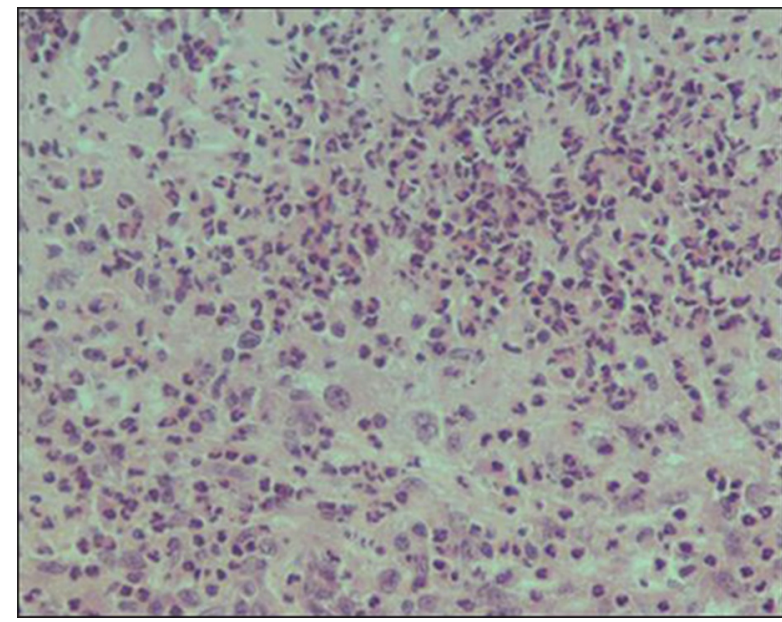

Figure-12: Chronic purulent endometritis: Note extensive neutrophilic infiltration, admixed with macrophages and lymphocytes, and occasionally foreign-body type giant cells (hematoxylin and eosin, 400x).

denuded basement membrane. The epithelial lining of endometrium was partly or completely sloughed and necrosed (Figure-13). Chronic granulomatous endometritis was noticed in two cases exhibiting the presence of micro granulomas (Figure-14). B. melitensis was isolated from these cases and was also confirmed by PCR using $O M P 31$ gene species-specific primers. In B. melitensis infected cases, the major uterine histopathological change was chronic endometritis characterized by infiltration of mainly mononuclear cells, lymphocytes, macrophages, epithelioid cells, and plasma cells in the mucosal and submucosal areas (Figure-15).

The tissue sections used for IHC in the present study were from samples found positive by PCR for $B$. melitensis. Positively stained tissue sections evinced foci of cells with cytoplasmic immunolabeling of macrophages indicating the presence of $B$. melitensis antigens/organisms in abundance, pushing the nuclei on the periphery (Figure-16).

Ovarian lesions occurred in frequency next to the uterine pathologies and included ovario-bursal 


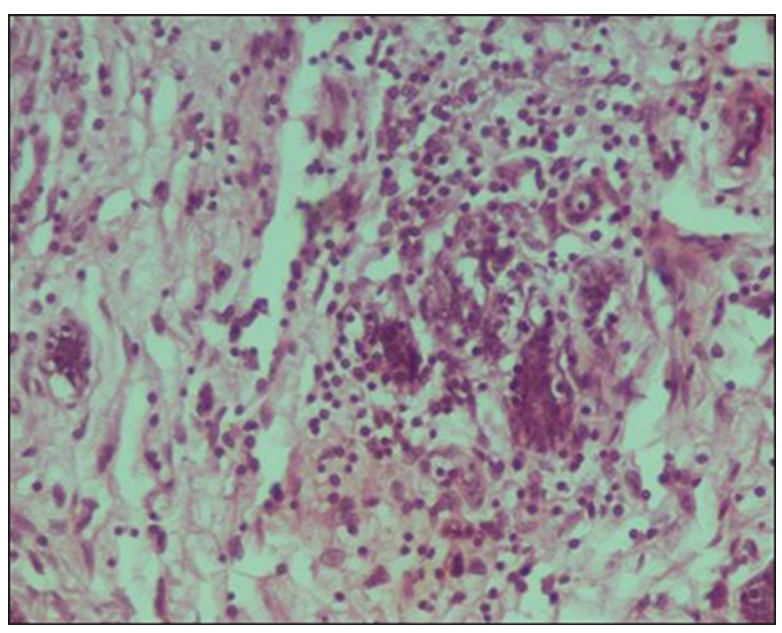

Figure-13: Chronic nonpurulent endometritis: Focal infiltration of lymphocytes, plasma cells, macrophages, and fibroblasts (hematoxylin and eosin, 400x).

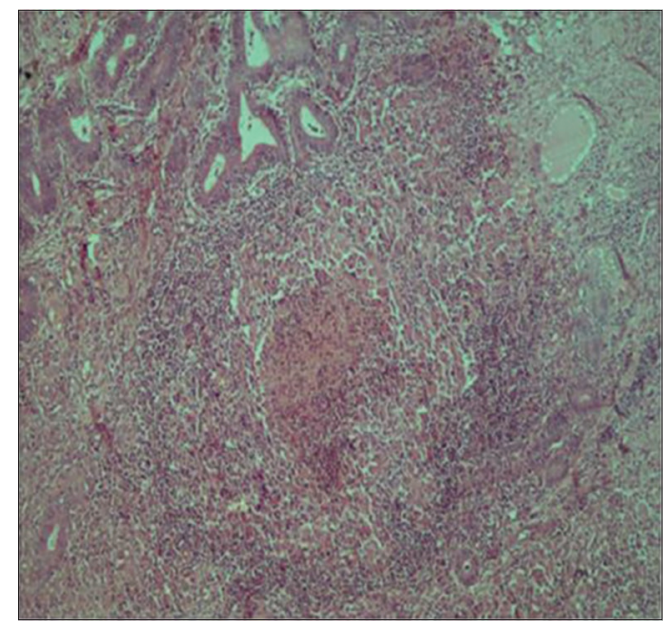

Figure-14: Chronic granulomatous endometritis: A discrete microgranuloma in uterine wall (hematoxylin and eosin, 400x).

adhesions, paraovarian cysts, polycystic ovary, cystic follicles, luteal cysts, ovarian tumor, ovarian atrophy, oophoritis, congestion, and hemorrhages. Ovarobursal adhesions were mostly seen in association with oophoritis. PCR test of affected tissues revealed the presence of potent pathogens such as Brucella and Campylobacter.

\section{Discussion}

Uterine infections not only disrupt the function of the uterus but also the ovary and the control centers in the hypothalamus and pituitary gland. Most uterine infections begin in the endometrium and are associated with mating, pregnancy, or postpartum uterine involution. Therefore, proper diagnosis and treatment of uterine diseases were considered as a key component of all reproduction management programs. In California, a survey revealed that $30 \%$ of uterine infections leading to abortion in goats were caused by bacteria, $4 \%$ by protozoa, and remaining by virus and fungi [19]. The presence of potentially pathogenic bacteria in the female genital tract might adversely

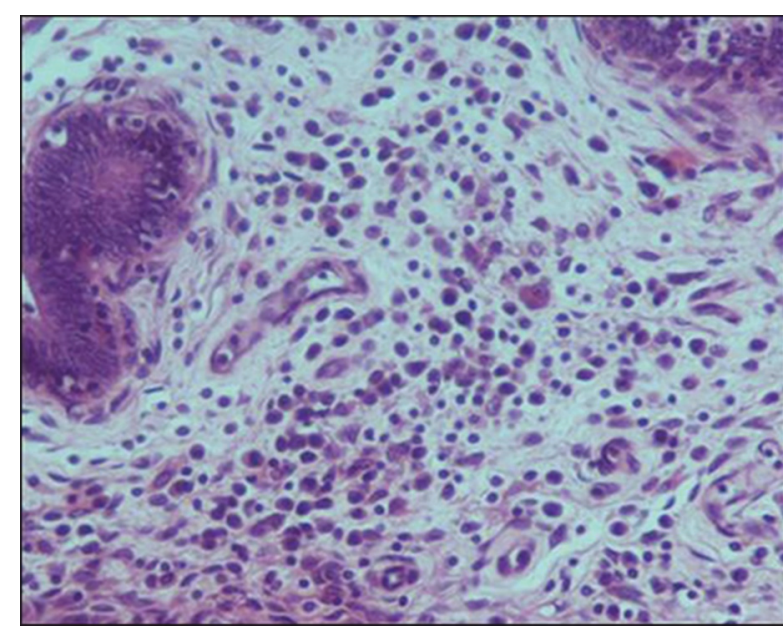

Figure-15: Chronic granulomatous endometritis: Mononuclear cells, lymphocytes, macrophages, epithelioid cells, and plasma cells in the submucosal area (hematoxylin and eosin, 400x).

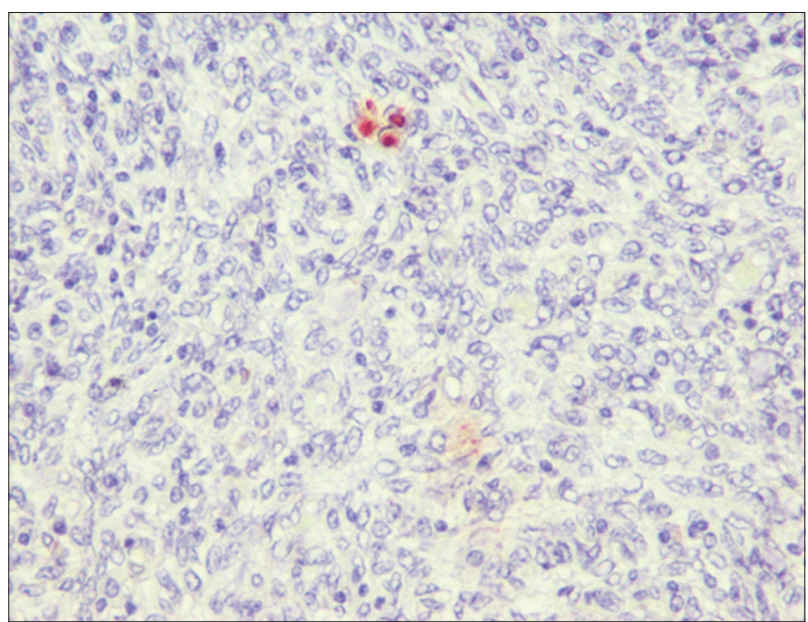

Figure-16: Uterus: Brucella melitensis-positive cytoplasmic immunolabeling of macrophages (IPO-3amino-9-ethylcarbazol-Mayer's hematoxylin counterstain, $400 \times)$.

affect the reproductive performance of sheep and goats [20].

The overall incidence of pathological lesions in the female genitalia of goats was found to be $16.3 \%$ in this study. This incidence was considered higher in comparison to the findings of Francis [7] and Archana et al. [21] who recorded incidences ranging from 1.9\% to $21.2 \%$. The variation in the incidence of pathological lesions in the present study compared to that of other workers from India or abroad might be due to differences in the breed of the animal, managemental practices, and climatic/geographical conditions.

The pathological conditions of the uterus were highest in the current study with an overall incidence of $12.42 \%$ [22]. Regularly observed gross lesion in the uterus was petechial hemorrhages on the tips of uterine caruncles. In majority of these cases, Campylobacter spp. infection was detected. An experimental study conducted by Hedstrom et al., in ewes, showed that gross lesions were present in caruncles of all 
Campylobacter jejuni inoculated ewes and revealed severe vasculitis and endometritis [23]. These findings corroborated with ours in which most of the uterine samples grossly exhibited hemorrhagic tips of caruncles which were positive for Campylobacter spp. infection by PCR.

In some cases, the lumen of uterine glands contained inflammatory cells along with the secretion. In Chlamydia infections, earlier workers observed the presence of neutrophils in uterine endometrial and submucosal glandular lumen in humans and guinea pigs, respectively $[24,25]$. Endometritis may follow certain conditions such as dystocia, fetal maceration, or retention of fetal membranes [26]. Pathogenic organisms such as Brucella and Chlamydia were isolated from acute endometritis cases of this study. Lymphoplasmacytic endometritis may be associated with persistent infection of Chlamydophila spp. [27].

In the present study, all the three positive cases of Chlamydia infection were seen in association with placental retention. Placental retention was frequently seen in chlamydial abortions of goats compared to sheep [28]. The presence of chlamydial antigens in the vagina, uterus, and uterine tubes after a year of abortion was confirmed by PCR and bolstered by demonstration of antigens in the uterus and fallopian tube using IHC [27]. However, we could not attempt IHC for Chlamydia infection presently. Rahman [29] from Bangladesh unsuccessfully attempted for isolation and identification of Chlamydiae from the reproductive tract of slaughtered does. Even though 9 species were present, Chlamydophila abortus was recognized as common etiological agent involved in small ruminant abortion [30]. In Hungary, during a study period of 7.5 years, it was found that the main cause for ovine and caprine abortions were Chlamydophila abortus infection with a prevalence of $46 \%$ and $17 \%$, respectively [31]. PCR proven to be a sensitive and reliable test has become an important diagnostic method for Chlamydia infection in animals $[32,33]$. The Chlamydiae are normally shed more abundantly in estrus than during the diestrus period [34].

Campylobacter spp. was detected in one particular case of purulent chronic endometritis by PCR. Rahman et al. [35] found that severe uterine infection causes subserosal abscess. Hence, it is assumed that the persistent Campylobacter infection leading to prolonged inflammatory reaction resulted in the development of myometrial abscess. Campylobacter spp., mainly $C$. jejuni and $C$. coli are the important etiological agents causing abortion as well as severe gastroenteritis in humans. Among slaughtered goat meat, there is $73 \%$ contamination by Campylobacter coli and $12 \%$ by $C$. jejuni infection. The studies in Eastern Congo, Ethiopia, and Nigeria revealed that Campylobacter in slaughtered animals occurs due to poor handling of carcass and cross contamination [36]. Overall, the prevalence of $34.6 \%$ of Campylobacter spp. was detected in goats slaughtered at Congo and in developing countries such as Iran, Pakistan, and Malaysia, and Campylobacter was reported in $9.4 \%$ of goat meat [37].

Toxoplasmosis is a widespread zoonotic disease caused by $T$. gondii characterized by abortions, stillbirth, mummification, and congenital anomalies depending on the stage of gestation in does as well as in humans. Sharma et al. [38] sited a low seroprevalence of $T$. gondii among the ruminants in India. They found antibodies for T. gondii in 7 of $186(3.763 \%)$ sheep, 2 of $83(2.409 \%)$ cattle, and 3 of $103(2.913 \%)$ buffaloes. These results indicated a low prevalence of T. gondii in ruminants tested. In Kerala, a total of 98 goats screened for the presence of toxoplasma antibodies, and 58 were found positive [39]. Among 13 seropositive goats, the uterus of one goat showed the presence of the parasite DNA by PCR in Brazil [40]. In the present study, all samples were negative for T. gondii by PCR.

B. melitensis, the etiological agent of brucellosis in goats, is a zoonotic infection and is most pathogenic for humans. Higher seroprevalence was recorded in female goats compared to male [41,42], providing a potential reservoir for the organism to propagate. A report from Egypt revealed that in each year the incidence of Brucella infection among slaughtered goats was found to be more compared to other species such as buffalo, sheep, and cattle [43]. These studies have confirmed that brucellosis is still endemic among the slaughtered animals in the study area and the prevalence is increased, especially among the small ruminants. In India, a few studies have reported the seroprevalence of brucellosis in goats of different states [44]. The cumulative incidence of brucellosis in sheep and goat was found to be $7.9 \%$ and $2.2 \%$, respectively [45]. However, there is no traceable report about the incidence of $B$. melitensis in genital tract of does. PCR test for Brucella using tissue samples was found to be $86 \%$ sensitive and $100 \%$ specific [46].

IHC on formalin-fixed paraffin-embedded tissues is a rapid, specific, useful technique for the diagnosis of B. melitensis infection [13]. In the present study, immunohistochemical staining was performed using standard $\mathrm{ABC}$ method for the detection of $B$. melitensis in the genitalia. Using this technique, the organism in the uterus could be located in the cytoplasm of inflammatory cells, especially the macrophages of fixed tissues [47]. These findings show the role of macrophages in Brucella infection. A study conducted previously in bucks infected with $B$. melitensis found that there was a positive correlation between the distribution of $B$. melitensis and IHC intensity [48]. In this study, out of total, 12 positive cases confirmed by species-specific (0MP31) PCR, 6 cases were subjected to IHC, and only 3 cases showed positive immunolabeling.

Bilateral hydrosalpinx causes sterility, but unilateral condition causes varying degrees of infertility in goats [7]. Hydrosalpinx occurs as a result of 
irreversible stage of inflammatory conditions and can make the animal sterile [2]. Earlier studies of hydrosalpinx in cattle revealed that the most prevalent bacteria recovered from hydrosalpinx conditions were Corynebacterium and Actinomyces with an incidence of $42.8 \%$ and $28.6 \%$, respectively [1]. Hence, it was confirmed that there was a correlation between bacterial isolates and hydrosalpinx. These organisms form emboli with consequent infarction and scarification, which will eventually block the lumen of the genital tract. Dawood reported a case of hydrosalpinx in infertile goats associated with cystic lesions in the genitalia [49]. In humans and animals, hydrosalpinx causes a negative effect on gametes and fertilization thereby lowering the endometrial receptivity and results in impairment or reduction in pregnancy rate [50].

In this study, ovarian lesions were seen as the second most prevalent lesion next to uterine pathologies [22]. The study revealed the presence of potent pathogens such as Brucella and Campylobacter causing inflammation and fibrinopurulent peritonitis which resulted in adhesion of ovary with bursa. Peritonitis or endometritis causes adhesion of ovary with either bursa or with salpinx in goats [7].

\section{Conclusion}

It is concluded from the study that different offending pathogens such as Brucella, Chlamydia, Corynebacterium, and Campylobacter were involved in causing various pathological conditions of female reproductive organs of goats. Most of the infectious reproductive problems in animals remain unnoticed until some clinical signs such as abortion or stillbirth develop. The best hope for reducing the infertility and sterility in animals depends on the early diagnosis of such pathogens that lead to infertility. In most of the cases, brucellosis and chlamydial infections could be difficult to differentiate; however, a battery of tests may be employed to facilitate their diagnosis including histopathology, PCR, and IHC for brucellosis. Goats attain early sexual maturity with regular and successful reproduction and produce about 2 kids/year. However, such prolificacy often fails to be attained on account of pathological problems related to genital tract in female goats. Most conventional farms only employ Brucella screening, but with this study, it is evident that the reproductive diseases and infertility are caused by other organisms including campylobacteriosis, chlamydia, and even corynebacterial infections. Hence, it is paramount to address the reproductive problem with broad unbiased diagnostic methods.

\section{Authors' Contributions}

VB, RVSP, and KG designed and conducted the research work. DDS, NKG, and AKM collected and analyzed the samples; VKG, RS, AKS, MK, and AK helped in preparing and reviewing the manuscript. All authors read and approved the final manuscript.

\section{Acknowledgements}

The authors are thankful to the Director of the ICAR-CIRG, Makhdoom, for providing necessary facilities and resources for carrying out the research work. The research work was funded by institutional budget (Project Code: ANSC CIRG SI 2012005 00216) received from the ICAR.

\section{Competing Interests}

The authors declare that they have no competing interests.

\section{References}

1. Azawi, O.I., Al-Abidy, H.F. and Ali, A.J. (2010) Pathological and bacteriological studies of hydrosalpinx in buffaloes. Reprod. Domest. Anim., 45(3): 416-420.

2. Ogunbodede, M.A., Oladele, G.M., Ode, O.J. and Ubah, S.A. (2014) Survey of gross abnormalities and microbial load on the female reproductive tract of Maradi goats slaughtered at Bodija abattoir, Nigeria. Adv. J. Agric. Res., 2(1): 1-7.

3. Ahmed, B.H., Hamad, R.J. and Abdelghafar, R.A. (2010) Ultrasonography for diagnosis of hydrometra and pyometra. Assiut Vet. Med. J., 56: 124.

4. Dunn, P.G.C. (1985) Goat veterinary society survey data, 1983 -1984 diseases of periparturient goat. GVSJ., 6: 49-50.

5. Dhaliwal, G.S., Murray, R.D. and Woldehiwet, Z. (2001) Some aspects of immunology of the bovine uterus related to treatments for bovine endometritis. Anim. Reprod. Sci., 67: $135-152$.

6. Hammon, D.S., Evjen, I.M., Dhiman, T.R., Goff, J.P. and Walters, J.L. (2006) Neutrophil function and energy status in Holstein cows with uterine health disorders. Vet. Immunol. Immunopathol., 113(1): 21-29.

7. Francis, M. (2009), Caprine Ovarian and Uterine Lesions: An Abattoir Survey. Thesis Doctoral Dissertation. Makerere University, Uganda. p6-42.

8. Tafti, K.A. and Davari, A. (2013) Congenital and acquired abnormalities of reproductive tract of non-pregnant ewes slaughtered in Fars province, Iran. Iran. J. Vet. Res., 14(2): 140-144.

9. El-Arabi,A.A., Taylor, D.J., Logue, D.N. and Benothman, M. (2013) Isolation and identification of bacterial flora from reproductive tracts of normal ewes in glasgow. J. Vet. Adv., 3(10): 275-280.

10. Nair, K.P. and Raja, C.K.S. (1972) Investigation on the pathological condition in the female genital organs of the goat. Kerala J. Vet. Sci., 3: 106-119.

11. Srivastava, A.K., Patil, V.K. and More, B.K. (1985) Incidence of various disorders in local angora and crossbred goats. Indian Vet. J., 62: 935-939.

12. Luna, L.G. (1972) Manual of Histologic Staining Methods of the Armed Forces Institute of Pathology. $3^{\text {rd }}$ ed. McGrawHill Book Company, New York. p38-39.

13. Ilhan, F. and Yener, Z. (2008) Immunohistochemically detection of Brucella melitensis antigens in cases of naturally occurring abortions in sheep. J. Vet. Diagn. Invest., 20(6): 803-806.

14. Vizcaíno, N., Cloeckaert, A., Zygmunt, M.S. and Dubray, G. (1996) Cloning, nucleotide sequence, and expression of the Brucella melitensis omp31 gene coding for an immunogenic major outer membrane protein. Infect. Immun., 64(9): 3744-3751

15. Hurtado, A., Aduriz, G., Moreno, B., Barandika, J. and García-Pérez, A.L. (2001) Single tube nested PCR for the detection of Toxoplasma gondii in fetal tissues from naturally aborted ewes. Vet. Parasitol., 102: 17-27.

16. Borel, N., Thoma, R., Spaeni, P., Weilenmann, R., 
Teankum, K., Brugnera, E., Zimmermann, D.R., Vaughan, L. and Pospischil, A. (2006) Chlamydia-related abortions in cattle from Graubunden, Switzerland. Vet. Pathol., 43(5): 702-708.

17. Çetinkaya, B., Karahan, M., Atil, E., Kalin, R., de Baere, T. and Vaneechoutte, M. (2002) Identification of Corynebacterium pseudotuberculosis isolates from sheep and goats by PCR. Vet. Microbiol., 88(1): 75-83.

18. Hall, T.A. (1999), Bio edit: A user-friendly biological sequence alignment editor and analysis program for windows 95/98/NT. In: Nucleic Acids symposium Series, c1979-c2000. Vol. 41. Information Retrieval Ltd., London. p95-98.

19. Moeller, R.B. (2001) Cause of caprine abortion: Diagnostic assessment of 211 cases (1991-1998). J. Vet. Diagn. Invest., 13: 265-270.

20. Shallali, A.A., Hussein, A.M., Salih, M.M. and Dafalla, E.A. (2001) A preliminary report on bacteria isolated from the female genital tract of Sudanese sheep and goats. Sudan. J. Vet. Res., 17(1): 55-63.

21. Archana, S., Vijay, M., Anita, B. and Indu, V. (2013) Pathological study on occurrence of various reproductive diseases in goats at Rajasthan. J. Immunol. Immunopathol., 15(1): 134.

22. Beena, V., Pawaiya, R.V.S., Shivasharanappa, N., Gururaj, K., Gupta, V.K., Gangwar, N.K., Singh, D.D., Karikalan, M., Sharma, A.K., Kumar, H., Kumar, A. and Singh, R. (2015) Occurrence of pathological conditions in the female genitalia of goats. Indian J. Vet. Pathol., 39(3): 197-201.

23. Hedstrom, O.R., Sonn, R.J., Lassen, E.D., Hultgren, B.D., Crisman, R.O., Smith, B.B. and Snyder, S.P. (1987) Pathology of Campylobacter jejuni abortion in sheep. Vet. Pathol., 24(5): 419-426.

24. Kiviat, N.B., Wølner-Hanssen, P., Eschenbach, D.A., Wasserheit, J.N., Paavonen, J.A., Bell, T.A. and Holmes, K.K. (1990) Endometrial histopathology in patients with culture-proved upper genital tract infection and laparoscopically diagnosed acute salpingitis. Am. J. Surg. Pathol., 14(2): 167-175.

25. Rank, R.G., Whittimore, J., Bowlin, A.K., DessusBabus, S. and Wyrick, P.B. (2008) chlamydiae and polymorphonuclear leukocytes: Unlikely allies in the spread of chlamydial infection. FEMS Immunol. Med. Microbiol., 54(1): 104-113.

26. Reddy, K.C.S, Reddy, V.S.C. and Rao, A.S. (1997) Studies on the incidence of reproductive abnormalities in local non-descript female goats. Indian J. Anim. Reprod., 18: 51-53.

27. Papp, J.R. and Shewen, P.E. (1996) Localization of chronic Chlamydia psittaci infection in the reproductive tract of sheep. J. Infect. Dis., 174(6): 1296-1302.

28. Stuen, S. and Longbottom, D. (2011) Treatment and control of chlamydial and rickettsial infections in sheep and goats. Vet. Clin. N. Am. Food Anim. Pract., 27(1): 213-233.

29. Rahman, M.H. (2006) Isolation and Identification of Chlamydiae from the Caprine Abortions and Reproductive Tract at Slaughter. Bangladesh Agricultural University, Research Progress. p17.

30. Nietfeld, J.C. (2001) Chlamydial infections in small ruminants. Vet. Clin. N. Am. Food Anim. Pract., 17(2): 301-314.

31. Szeredi, L., Jánosi, S., Tenk, M., Tekes, L., Bozsó, M., Deim, Z. and Molnár, T. (2006) Epidemiological and pathological study on the causes of abortion in sheep and goats in Hungary (1998-2005). Acta. Vet. Hung., 54(4): 503-515.

32. Berri, M., Rekiki, A., Boumedine, K.S. and Rodolakis, A. (2009) Simultaneous differential detection of Chlamydophila abortus, Chlamydophila pecorum and Coxiella burnetii from aborted ruminant's clinical samples using multiplex
PCR. BMC Microbiol., 9(1): 130

33. Navarro, J.A., Ortega, N., Buendia, A.J., Gallego, M.C., Martínez, C.M., Caro, M.R. and Salinas, J. (2009) Diagnosis of placental pathogens in small ruminants by immunohistochemistry and PCR on paraffin-embedded samples. Vet. Rec., 165(6): 175-178.

34. Livingstone, M., Wheelhouse, N., Maley, S.W. and Longbottom, D. (2009) Molecular detection of Chlamydophila abortus in post-abortion sheep at oestrus and subsequent lambing. Vet. Microbiol., 135(1): 134-141.

35. Rahman, M.H., Chowdhury, E.H., Saha, S.S., Islam, A. and Alam, M.G.S. (2008) Abattoir study of reproductive diseases in goats. Bangladesh Vet., 25(2): 88-91.

36. Salihu, M.D., Junaidu, A.U., Oboegbulem, S.I., Egwu, G.O., Tambuwal, F.M. and Yakubu, Y. (2009) Prevalence of Campylobacter species in apparently healthy goats in Sokoto state (North Western) Nigeria. Afr. J. Microbiol. Res., 3(9): 572-574.

37. Mpalang, R.K., Boreux, R., Melin, P., Daube, G. and de Mol, P. (2014) Prevalence of Campylobacter among goats and retail goat meat in Congo. J. Infect. Dev. Ctries., 8(2): 168-175.

38. Sharma, S., Sandhu, K.S., Bal, M.S., Kumar, H., Verma, S. and Dubey, J.P. (2008) Serological survey of antibodies to Toxoplasma gondii in sheep, cattle, and buffaloes in Punjab. J. Parasitol., 94(5): 1174-1175.

39. Syamala, K., Devada, K. and Pillai, K.M. (2008) Diagnosis of caprine toxoplasmosis by latex agglutination test. J. Vet. Anim. Sci., 39: 53-54.

40. Bezerra, M.J., Cruz, J.A., Kung, E.S., Silva, J.G., Santos, A.S., Moraes, É.P. and Mota, R.A. (2014) Occurrence of Toxoplasma gondii DNA in sheep naturally infected and slaughtered in abattoirs in Pernambuco, Brazil. Pesqui. Vet. Bras., 34(4): 329-331.

41. Akhter, L., Islam, M.A., Das, S. and Khatun, M.M. (2014) Seroprevalence of brucellosis and its associated risk factors in sheep and goat in the farms and slaughter house in Mymensingh, Bangladesh. Microbes Health, 3(1): 25-28.

42. Rahman, M.S., Faruk, M.O., Her, M., Kim, J.Y., Kang, S.I. and Jung, S.C. (2011) Prevalence of brucellosis in ruminants in Bangladesh. Vet. Med., 56(8): 379-385.

43. Fatma, H.M. and Mahdey, E.A. (2010) Incidence of Brucella species in slaughtered food animals and its edible offal at Beni Suef, Egypt. Glob. Vet., 5(5): 248-254.

44. Reddy, D.A., Kumari, G., Rajagunalan, S., Singh, D.K., Kumar, A. and Kumar, P.P. (2014) Seroprevalence of caprine brucellosis in Karnataka. Vet. World, 7(3): 182-188.

45. Renukaradhya, G.J., Isloor, S. and Rajasekhar, M. (2002) Epidemiology, zoonotic aspects, vaccination and control/ eradication of brucellosis in India. Vet. Microbiol., 90(1): 183-195.

46. Gupta, V.K., Rout, P.K. and Vihan, V.S. (2007) Induction of immune response in mice with a DNA vaccine encoding outer membrane protein (omp31) of Brucella melitensis 16M. Res. Vet. Sci., 82(3): 305-313.

47. Xavier, M.N., Paixao, T.A., den Hartigh, A.B., Tsolis, R.M. and Santos, R.L. (2010) Pathogenesis of Brucella spp. Open Vet. Sci. J., 4: 109-118.

48. Nasruddin, N.S., Mazlan, M., Saad, M.Z., Hamzah, H. and Sabri, J. (2014) Histopathology and immunohistochemistry assessments of acute experimental infection by Brucella melitensis in bucks. J. Pathol., 4(2): 54.

49. Dawood, K.E. (2011) Hydrosalpinx and hydro bursitis in infertile goats. Turk. J. Vet. Anim. Sci., 34(5): 477-480.

50. Arrighi, S., Cremonesi, F., Bosi, G., Groppetti, D. and Pecile, A. (2007) Characterization of a population of unique granular lymphocytes in a bitch deciduoma, using a panel of histo- and immunohistochemical markers. Vet. Pathol., 44: 521-524. 